\title{
Pandemic, social isolation and the importance of people-plant interaction
}

\author{
Simone Novaes Reis ${ }^{1 *}$ (D) Michele Valquíria dos Reis ${ }^{2}$ (1), Ângela Maria Pereira do Nascimento ${ }^{2}$ (D) \\ ${ }^{1}$ Empresa de Pesquisa Agropecuária de Minas Gerais, Campo Experimental Risoleta Neves, São João del Rei-MG, Brazil. \\ ${ }^{2}$ Universidade Federal de Lavras, Departamento de Agricultura, Lavras-MG, Brazil
}

\begin{abstract}
The COVID-19 pandemic has brought drastic routine changes to the world's population. Social isolation, one of the recommended practices to curb the spread of the disease, can lead to the development of several problems, such as depression, stress, apathy and loneliness. However, practices associated with the cultivation and contemplation of flowers and ornamental plants can be an option to aid in the care for the mental health of the population. It has been proven that hortitherapy helps in the treatment of mental illness, in the recovery of patients. Biophilia incorporated into architectural design and gardening, as a hobby and occupational therapy, can also be used to improve physical and mental health. Activities can be done indoors, outdoors or even virtual, with flowers and plants used as supporting instruments to make the population feel better, including the situation experienced by the period of seclusion.
\end{abstract}

Keywords: coronavirus, COVID-19, floriculture, gardening, life quality.

\section{Resumo}

Pandemia e isolamento social - importância da interação plantas-pessoas

A pandemia de COVID-19 trouxe mudanças drásticas de rotina para a população mundial. O isolamento social, uma das práticas recomendadas para conter o avanço da doença, pode levar ao desenvolvimento de problemas diversos, como, a depressão, estresse, apatia e solidão. Mas práticas associadas ao cultivo e contemplação de flores e plantas ornamentais podem ser uma opção no auxílio ao cuidado com a saúde mental da população. Comprovadamente, a hortiterapia auxilia no tratamento de doenças mentais, na recuperação de doentes. Também a biofilia incorporada ao design arquitetônico e a jardinagem, como hobby e terapia ocupacional, pode ser utilizada para melhoria da saúde física e mental. As atividades podem ser feitas em ambientes internos, externos ou até mesmo virtuais, sendo as flores e plantas instrumentos de apoio para que a população se sinta melhor, incluindo a situação vivida pelo período de reclusão.

Palavras-chaves: coronavírus, COVID-19, floricultura, jardinagem, qualidade de vida.

\section{Introduction}

The coronavirus outbreak (COVID-19) caused by SARS coronavirus 2 (SARS-CoV-2) (Yu et al., 2020) was declared by the World Health Organization (WHO) on January 30, 2020 and reached the highest level - Public Health Emergency of international importance, and characterized as a pandemic, on March 11 of the same year. The term pandemic refers to the geographical distribution of the disease, that is, the virus causes outbreaks in several regions of the world (PAHO, 2020a).
The pandemic caused by COVID-19 is considered a serious health problem, mainly since most of the infected individuals do not manifest symptoms, and can transmit the disease (Amaral, 2020). Studies on the disease are ongoing and new information emerges as research progresses, but there is evidence that pre-symptomatic people are able to transmit the virus, one to three days before they manifest their first symptoms (WHO, 2020a). The ease with which the virus is transmitted, through secretions, sneezing, coughing, saliva droplets and close contact between people or with contaminated surfaces makes it even more

*Corresponding author: simonereis@epamig.br 
contagious (Yu et al., 2020). Another aggravating factor according to Amaral (2020) is the lack of resources to attend to a large number of simultaneous cases, such as beds, equipment and qualified professionals for the intensive treatment that the disease requires.

Some measures must be taken to control the spread while antiviral drugs or vaccines are not available for a specific type of virus, as is the case with COVID-19 (PAHO, 2020b; $\mathrm{Yu}$ et al., 2020). Called non-pharmacological interventions (NPIs), these measures can be effective in reducing the impact of the pandemic, delaying the contamination peak and enabling health services to be equipped to receive and treat the most severe cases of the disease (PAHO, 2020b).

According to the Pan American Health Organization PAHO (PAHO, 2020b), in cases of recent pandemics, such as those caused by the Influenza virus, protocols establish some NPIs such as personal hygiene, isolation of critically ill patients, quarantine for people exposed to the virus and even the closure of schools and workplaces.

After the record of the first case in Brazil, several measures were taken to contain the epidemic. Such measures varied among Federal, State and Municipal spheres, but one of the main ones was social isolation (or social distancing), recommended worldwide (Wang et al., 2020). For this measure to be effective, schools were closed, as well as universities, parks and other public areas, commerce in general, and only commercial buildings that sell items considered essential remained open (Bezerra et al., 2020). Leisure venues such as bars, restaurants, gyms and clubs were closed, and concerts and events in general were cancelled, avoiding crowds.

The necessary isolation is essential, since COVID-19 is a contagious disease, with a high rate of transmission and mortality, and its effectiveness is greater when the measure is adopted soon after the pandemic is confirmed (Ceccon and Schneider, 2020).

As a result of social isolation, there were changes in the habits and routines of families, which can lead to several changes in mental health in people of all ages. Symptoms such as difficulty concentrating, irritability and nervousness can be observed (UN, 2020). Depression, sadness, stress and anxiety can also affect people at this period. Stress is mainly related to the volume of available information which does not always bring clear data with respect to risks, duration of the pandemic, impact on the economy, among other factors.

Women are even more burdened with the multitasking that they are forced to perform at the moment: family care, direct assistance with their children's school activities, the house, obligations with remote work, besides insecurity and fear (UN, 2020). The situation is even more serious when the issue analyzed is domestic violence, as the reporting of cases during the pandemic has also increased (WHO, 2020b).

The concern over physical and mental health in the context of the pandemic generated a series of recommendations for practices that assist the population in activities that can be developed at home or remotely, as in the case of physical exercises, with benefits such as the preservation of muscle mass levels and strength (Ferreira Jr. et al., 2020). The Cultural Association of Occupational Therapists of the State of Paraná (ACTOEP) published the guide "Practical guidelines for healthy routines" (ACTOEP, 2020). In this guide, some activities for the period are suggested, from domestic routines to the maintenance of gardens and online courses to feel productive. The ACTOEP also suggests that personal projects, considered forgotten, can be put into practice, such as organizing and implementing a garden and growing plants in pots, as a way to bring more harmony to the homes.

However, it is important to emphasize that gardening or horticultural practices are based on research, studies and scientific publications, which reinforces their importance for this phase that the population experiences.

Given to this, the objective was to demonstrate the importance of flowers, ornamental plants and gardens as practices that lead to well-being and good mental health.

\section{Contact with nature}

Contact with nature is related to human well-being and health (Bratman et al., 2012; Martin et al., 2020). Several scientific studies have demonstrated the positive effects of exposure to green, such as reducing stress, feeling of happiness, improving recovery from surgery, reducing vascular diseases, practicing physical activities, mental health, among other benefits (Chang and Chen, 2005; Keniger et al., 2013, Buckley, 2020; Fagerholm et al., 2020).

People exposed to environments with the presence of nature, had low frequency brain waves and less brain activity in the frontal areas, indicating restorative and comfortable feelings (Norwood et al., 2019). In addition, contact with nature can act as an attenuator of negative health impacts arising from stressful life events (Van den Berg et al., 2010).

In the last decades, the frantic pace of the urbanization process and the increased use of technologies have had negative effects on people's well-being and physical and mental health due to the distance from natural environments. Among the main problems detected, there is an increase in obesity rates, vitamin D deficit and diagnosed cases of Attention Deficit Hyperactivity Disorder in children. This disconnect with "nature" and its effects on human beings gave rise to Nature Deficit Disorder (Louv, 2016).

Despite of the importance of contact with nature, in large urban centers, people live in increasingly smaller spaces, surrounded by concrete. In many cases, contact with nature is limited to sporadic visits to green areas such as parks and squares. However, during this period of social isolation, there is limited visitation to green areas, which leads to a deficiency in contact with nature. An environment devoid of nature can have a negative effect on health, productivity and well-being.

Ulrich's Psycho-evolutionary Theory was one of the first approaches regarding the beneficial effects of contact with nature for people's psychological well-being. Stress recovery encompasses aesthetic integration and affective responses to a natural environment. And the healing power 
of nature is, in part, an unconscious and autonomic response to natural elements. This can happen without awareness, especially in individuals under stress conditions. The health benefits of nature are evidenced by contact, contemplation and even the visualization of a simulation of nature, such as a photograph of a natural landscape (Ulrich, 1979; Ulrich et al., 1991).

In view of the above, the presence of green in all types of environments must be encouraged: external, internal, residential, professional, schools and hospitals, especially during this period of social isolation. In the current context, this may be the only type of contact with nature for many people, especially in large urban centers. One way to pursue these benefits is through the use of biophilic design.

\section{Biophilia}

This design is based on the hypothesis of biophilia (biolife, philia-love) which suggests that human beings have an innate biological connection with nature (Wilson, 1984). Thus, biophilic design seeks to incorporate natural features and elements into the built environment. This form of green insertion has received increasing attention in the fields of design and health (Yin et al., 2018).

Biophilic design affects how humans feel, work and create and, by connecting to the nature that inspires, productivity is increased, even contributing to a greater sense of well-being. The psychological and health benefits of biophilic architecture are already proven. The use of elements of biophilic design affects the recovery of people in situation of stress and anxiety. People who were exposed to biophilic indoor environments consistently had better recovery responses after stressors, compared to those in the non-biophilic environment, in terms of reduced stress and anxiety (Yin et al., 2020). The effects on physiological responses are immediate after exposure to ambient biophilic substances.

Therefore, the incorporation of nature in interior design can play an important role in creating an environment that leads to physical and mental health (Cantor et al., 2013). Thus, when living with ornamental indoor plants, the human being can benefit from the fresh air provided, which induces pleasant effects and relaxation (Cantor et al., 2013).

The type of views from windows and indoor plants affects human psychophysiological responses in work environments. In a scientific study conducted in Taiwan, participants were less nervous or anxious when watching a view of nature and/or when indoor plants were present. However, when neither the window view nor the indoor plants were shown, the participants experienced the highest degree of tension and anxiety (Chang and Chen, 2005).

\section{Gardening as a hobby/therapy}

Connecting with nature is part of the human development process and, in times of social isolation, limiting access to green areas tends to aggravate the damage to people's physical and mental health. Bringing nature to indoor spaces can effectively increase contact with the natural environment, which can be beneficial for health and comfort (Deng and Deng, 2018). In this context, the practice of activities such as gardening, horticulture, making and buying floral arrangements and contemplating residential gardens can be important allies for health preservation and recovery.

Plants have long been used to satisfy different types of human needs on a daily basis. They are deeply involved in meeting the requirements in nutrition, vitamins, calories, oxygen, fuel and medicinal phytochemicals, among others (Odeh and Guy, 2017). However, that relationship goes beyond their use as plant products. Plants are grown for their desired aesthetic and/or sensory characteristics.

Ornamental plants provide essential environmental, economic, social and aesthetic benefits for human well-being. Intentionally cultivated for decoration and beautification of internal and external environments, they have gained more prominence in recent years as a necessary and not superfluous asset.

The people-plant interaction provides stability through contact with nature, mediating relationships with other people and building the aesthetics of environments. Given this knowledge, gardening activities can be used as occupational therapies.

According to the American Horticultural Therapy Association - AHTA, gardening as a therapy was first documented by Dr. Benjamin Rush, for the treatment of mental illness. Later, in the 1940s and 1950s, the practice was used in the rehabilitation of war veterans and, from then on, it was adopted to assist in the treatment of different types of diagnosis (AHTA, 2020).

Souza and Miranda (2017) evaluated projects that used horticultural therapy as a way to collaborate for the reintegration of patients with mental disorders. In the evaluation of the results of these projects, there were reports on the part of the patients of feelings of pleasure, disposition, joy, well-being and also of being useful, as results of the horticultural practices that included the work in vegetable gardens and gardens.

Household gardens, associated ornamental plants and horticultural practices particularly contribute to the development of cultural ecosystem services, such as "aesthetic quality", "recreation", "resilience", "social cohesion", "biophilia" and "tranquility" (Cetinkaya and Çiftçioğlu, 2019; Ciftcioglu et al., 2019).

Not only can horticultural and gardening activities be interesting tools for children during the period of social isolation, but in everyday life and in school programs.

Children who practice horticultural activities for 5 minutes have better physiological relaxation, suppressing the activity of the sympathetic nervous system and skin conductance, compared to the use of the mobile phone (Shao et al., 2020). In addition, gardening tends to relieve anxiety levels and provides several positive health benefits, such as comfort, relaxation, joy and natural emotions for children (Dyg and Wistoft, 2018). Children could benefit physiologically and psychologically from horticultural/ gardening activities (Figure 1). 

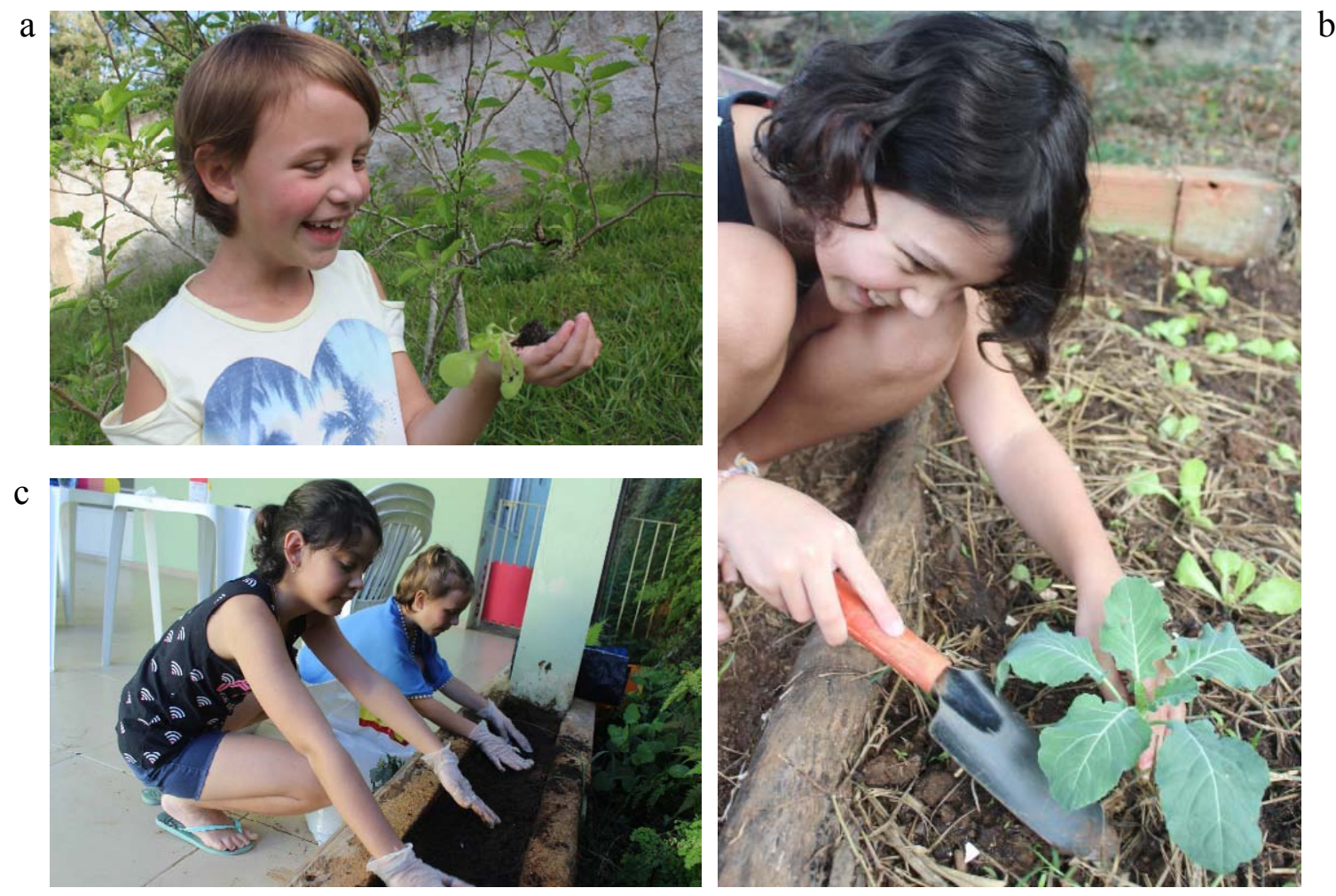

C

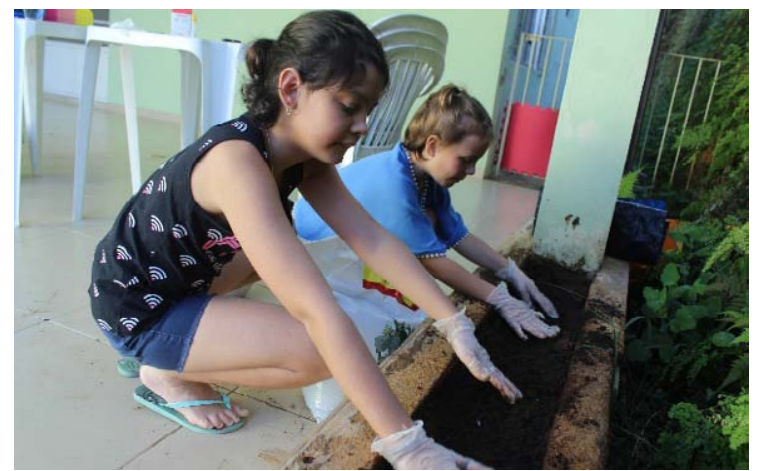

Figure 1. Children developing horticulture (A and B) and gardening activities $(C)$ at home.

(Photos publication formally authorized by the parents).

In addition, the practice of horticulture and gardening leads the brain to produce stimuli, through the cognitive system, of well-being and happiness. When people with mental disabilities work with plants, for example, forming their own gardens, they feel capable, stimulating this person's emotional development (Relf, 1992; Cooper, 2005). In addition, the therapeutic benefits of gardens can be attributed to encouraging physical activities, reducing the level of stress and mental tiredness, besides a greater cultural and social integration (Armstrong, 2000).

Astronauts on space missions experience long periods of isolation, confinement and without a biophilic natural environment. These conditions can cause psychosocial and neurocognitive impairments. To alleviate these periods of isolation, studies have been conducted with the use of therapeutic benefits mediated by plants (Odeh and Guy, 2017). Thus, NASA astronauts indicate the practice of hobbies to maintain mental health during isolation, one of which is the care of plants, which can be developed even in small environments (Cantor et al., 2013).

Nature stimulates our senses, providing well-being through light, color, sound, smell, texture and shape; thus, when starting any activity with plants, it is interesting to explore the senses to the fullest to obtain the maximum benefits. Adequate lighting influences endocrine control, biological clock, sexual development, regulation of stress and fatigue, and melatonin suppression (Fonseca et al., 2005). Color causes sensory stimuli, triggering cozy, stimulating sensations or the highlighting of some element.

Aromas have therapeutic effects, as they affect our emotions, acting on the limbic system, which also acts on the control of body functions. In gardens, in addition to fragrant flowers and plants, it is possible to feel the pleasant aroma of herbs and homemade spices used in the recipes preparation (Chimentti and Cruz, 2006). Smell has a very intimate relationship with the emotional side and makes the fastest way to connect with the brain, stimulating it to rescue memories (Gappell, 1995). Plant textures and shapes contribute a lot to the enrichment of the environment, produce positive effects, breaking the monotony. The shapes must be harmonious, stimulating curiosity with constant changes in the visual field (Paiva, 2008).

Gardens can be implemented relatively quickly and serve different groups of people, including children, the elderly and people with disabilities. A regular dose of gardening can improve physical, psychological and social health. Thus, in a long-term perspective, alleviate and prevent various health problems that today's society faces (Soga et al., 2017).

\section{Lawns}

Lawns are used in residential gardens, sports areas, public works, schools and industrial parks, bringing various aesthetic and environmental benefits, in addition to causing physiological and psychological well-being.

In addition to providing an aesthetically pleasing surface for outdoor activities, lawns also play a number of ecological roles, such as: erosion control, oxygen production, fixing atmospheric carbon dioxide, water infiltration into the soil, biodegradation of synthetic organic compounds, suppression of undesirable plants and reduction in fire risk. In urban environments, they contribute to noise attenuation, heat dissipation and stress reduction in human populations (Stier et al., 2013; Ghimire et al., 2016). 
Another use of ornamental lawns in landscape architecture is in its planting on green roofs and ecological sidewalks (Santos et al., 2016; Santos et al., 2015), which also contribute to the environmental benefits in urban spaces.

Lawn cultivation is a popular agricultural practice associated with the life quality of urban populations as a result of their ability to comprise safe, pleasant and appropriate environments for sports and recreational activities (Souza et al., 2016).
Considering the importance of contact with nature for people's health, lawns in the urban environment play an important social and psychological role, improving people's quality of life, favoring social harmony, productivity, physical and mental health, providing a suitable environment for a variety of recreational and social activities (Pretty et al., 2007). During this period of isolation, the lawn in residential gardens can be used in different ways: an openair living room, space for children's play, sports, reading and sunbathing, family picnics, among others (Figure 2).

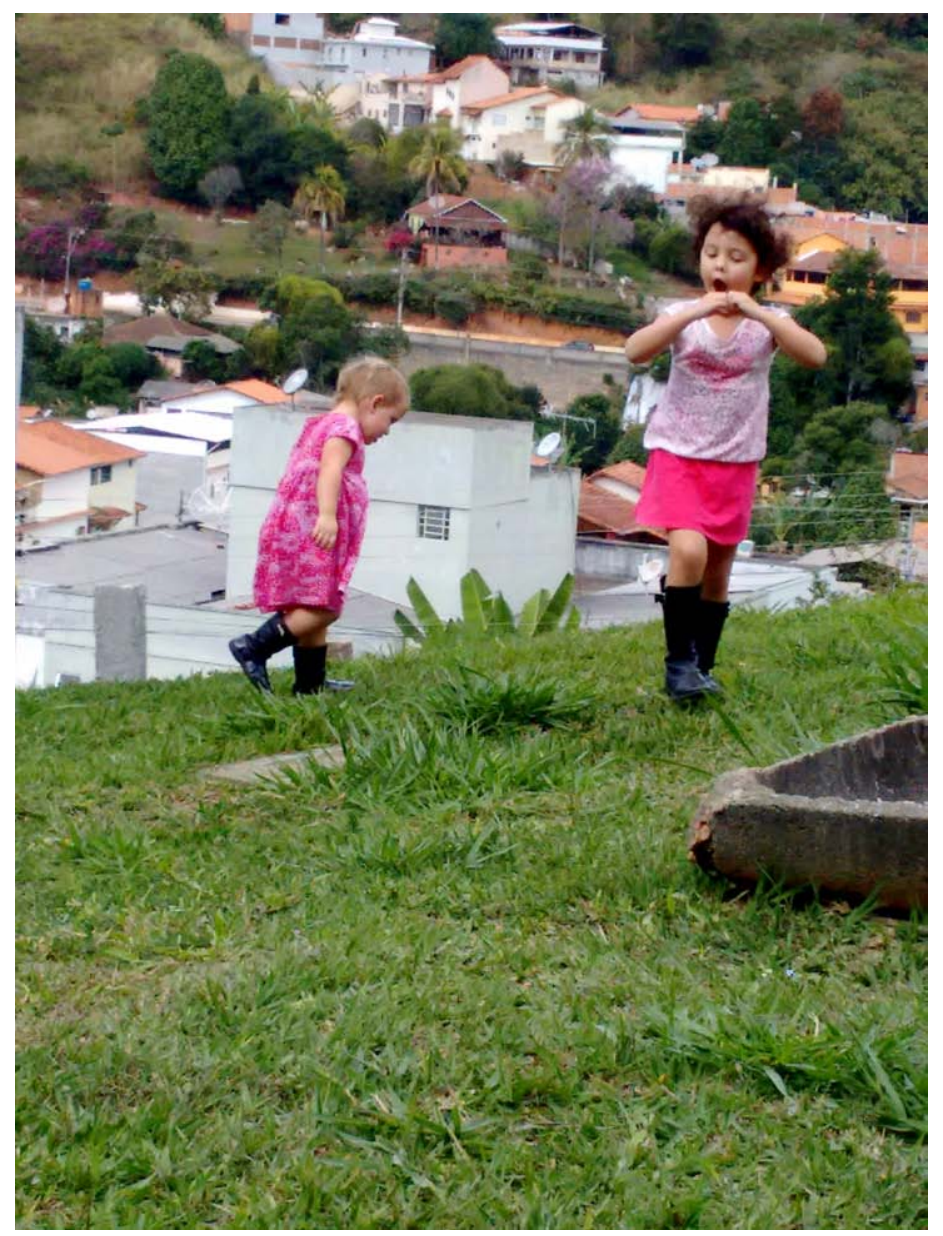

Figure 2. Residential garden - lawn used as a place for child's play.

(Photos publication formally authorized by the parents).

It is important to observe that lawns in public parks and sports squares commonly require large investments in maintenance (Garbuzov et al., 2015). Since these areas are closed to the public and for sporting events, maintaining them is necessary since, once the period of seclusion has passed, the tendency is for the population to seek these spaces more frequently.

\section{Indoor plants}

A considerable portion of the population in large urban centers lives in small properties where there is no space for gardens. Large building condominiums may have landscaped spaces but, with the restriction on social living, they are little or not used. The cultivation of indoor plants becomes yet another option for getting closer to nature.

The quality of indoor air must be observed during this period of social isolation, as the proportion of time people spend indoors is high and many of these environments have reduced ventilation rates. One way to improve the quality of these spaces is by inserting indoor plants (Aydogan and Cerone, 2020).

Research has been carried out to better understand these benefits and potential of incorporating plants into the internal environment, and NASA (National Aeronautics and Space Administration) is one of the pioneers in these 
studies. Research evaluates the use of plants to remove pollutants and maintain a safe breathing environment (Wolverton et al., 1989; NASA, 2020).

During photosynthesis, plants absorb carbon dioxide and release oxygen, significantly contributing to air quality. Plants are also potent in removing different air pollutants indoors. They can reduce airborne contaminants, such as nitrogen oxides, volatile organic compounds (VOCs), dust, acetones, pesticides, cleaning products, tobacco smoke, fungi and bacteria, insulation and furniture, among others (Orwell et al., 2004; Irga et al., 2018; Pettit et al., 2018; Aydogan and Cerone, 2020).

Sansevieria trifasciata and Chlorophytum comosum can be used as efficient botanical biofilters for phytoremediation of multiple pollutants from cigarette smoke (Siswanto et al., 2020). Zamioculcas zamiifolia absorbs formaldehyde (used in building materials, carpets, paints and cosmetics, etc.) and toluene (present in furniture, paints, oils, adhesives, leather tanning and disinfectants, etc.) (Ullah et al., 2020).

Plants grown on substrate may also have additional benefits from soil microorganisms to clean VOCcontaminated air. The interactions between plant/soil and certain microorganisms, which support and develop each other, form a complementary biofiltration system (Orwell et al., 2004). In addition to eliminating air pollutants, plants can decompose some odor molecules in an indoor environment (Oyabu et al., 2003), eliminating possible unpleasant smells.

Many ornamental plants still release pleasant aromas, which perfume the environment, bringing comfort and well being. In addition to these air purification benefits, plants also release water vapor, leaving the environment more humid and refreshing. The presence of plants in the environment is correlated with a $23 \%$ decrease in dry/ hoarse throat levels and dry facial skin (Fjeld et al., 1998).

Another positive aspect of the insertion of plants to improve the quality of indoor environments is the low cost for implanting potted plants. In addition, potted plants have the flexibility to move indoors, in which people spend most of their time, as well as ample possibilities for plant combinations. Thus, it is a solution to improve air quality, while contributing to the aesthetics of the environment and offering psychological, physiological and cognitive benefits (Aydogan and Cerone, 2020).

Another way of inserting green into indoor environments is the use of green walls. There are simpler and less costly models to implement, as well as those more expensive, but they require less maintenance work. Green walls can also provide all the improvements in the quality of the environment (air purification and humidity) than isolated plants in pots. Green walls contribute to improving the thermal performance of environments, thus reducing energy costs and increasing air quality (Feng and Hewage, 2014).

In addition, the presence of green walls is related to an improvement in physiological and psychological human relaxation compared to the wall without the presence of vegetation. People who viewed green walls showed brain activities correlated with the feeling of comfort and relaxation, as well as a significantly improved mood (Elsadek et al., 2019).

Interior design that includes plants will provide a richer sensory environment, reducing stress, promoting learning, recovery and involvement in therapeutic interventions (Odeh and Guy, 2017). For the practice of gardening at home, it is important to consider several aspects, mainly the provision of the appropriate conditions for the development of the species in question.

Indoor plants should lead to communication and interaction between users. The chosen species must stimulate the cognitive senses, providing positivism and well-being through contact with nature (Figure 3 ). As far as possible, there must be a variety of species; trees and flowers that attract birds and butterflies, plants that bloom in different seasons, different colors, textures and aromas. The presence of water in the form of small fountains, waterfalls or water mirrors also produces well-being through noise and freshness. 


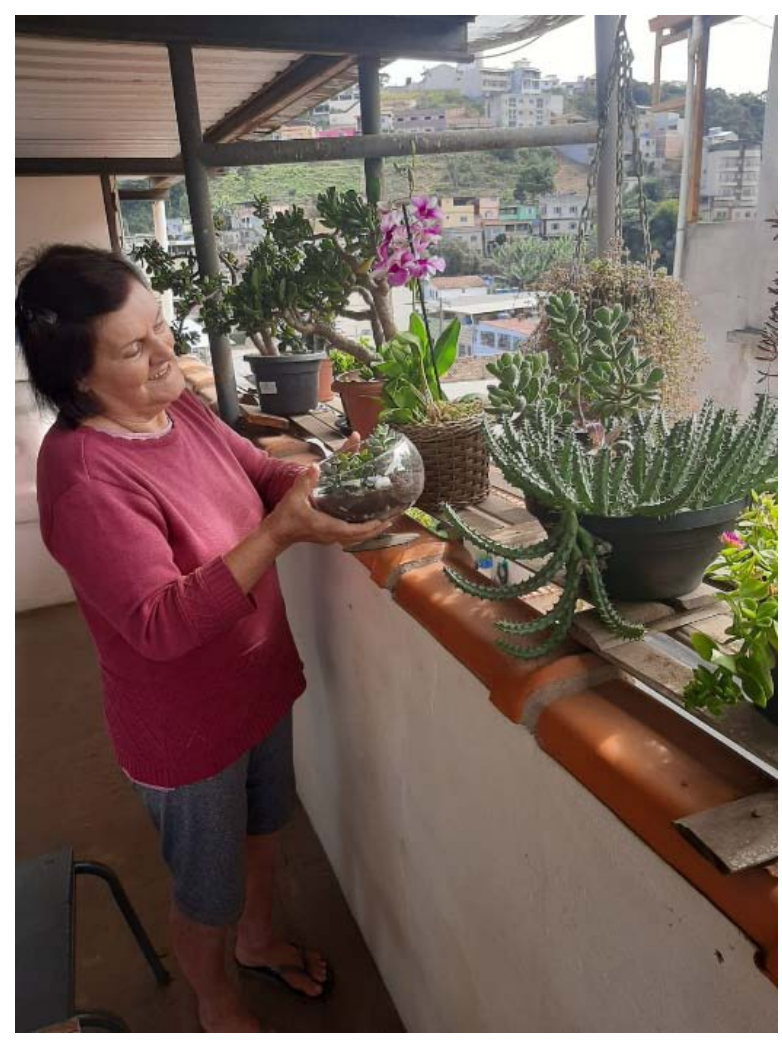

Figure 3. Indoor plants - contact with plants helps with physical and psychological well-being.

Another important aspect is the creation of spaces with characteristics of familiarity, comfort and tranquility. The use of known plants is important, as they create an environment that portrays family coziness, bringing a sense of well-being to the people who use the space (Cooper, 2005). The space must also provide a security effect: it is necessary that people feel safe, but without the idea of imprisonment (Constantino, 2004).

\section{Pandemic and social networks}

Most Brazilians access the internet and have information sources in the virtual environment that can be used for entertainment, work and education.

The increase in lives - live streams - since the beginning of the pandemic was significant and companies, artists, service providers, among others, began to interact more intensely with the public through different platforms, such as Instagram, Facebook and YouTube (Agrela et al., 2020). The growth in the search for live content on YouTube was over $4900 \%$, with a larger audience than that of recorded content. In the field of sciences, one of the most prominent lives addressed important topics to inform the population about the coronavirus, reaching 380 thousand people watching simultaneously (Agrela et al., 2020).

In the floriculture and landscaping sector, interaction through the web has also been taking place. During this period of social isolation, several professionals in the fields of gardening, landscaping and decoration have made lives on social networks and they have attracted thousands of people in search of learning and improvement. How to take care of your plants, Make your seedlings at home and Use of cut flowers in different arrangements are topics intended for the general public. There are reports of lives with over 20 thousand people participating simultaneously. For example, Floral Atlanta, specializing in accessories and materials for floral arrangements and event decoration, organized lives for several days in a row, under the title "Flowers at home", inviting renowned floral artists to demonstrate live techniques, and stimulate the consumption of flowers (Floral Atlanta, 2020). To carry out the online events, the company had the support of Veiling Holambra Cooperative, flower producers and distributors - Terra Viva and Holambelo, in addition to the Brazilian Academy of Floral Arts - ABAF.

Some lives have a more technical bias and are directed to a specific audience, aimed at professional improvement. With the crisis faced by the sector due to the pandemic, others aimed to inform the public, growers and technicians in the sector about the situation. Veiling Holambra, Phenoglad team, Canal Terra Viva, Emater Minas and others, promoted interviews addressing floriculture, from production to commercialization (Canal Terra Viva, 2020; Emater Minas, 2020; Phenoglad, 2020; Veiling Holambra, 2020b). According to Nereu Streck, coordinator of the Phenoglad profile on Instagram, there were 13 lives held from April to June 2020 (Figure 4), covering various topics related to floriculture, with an audience of 4213 participants (Streck, 20203). 

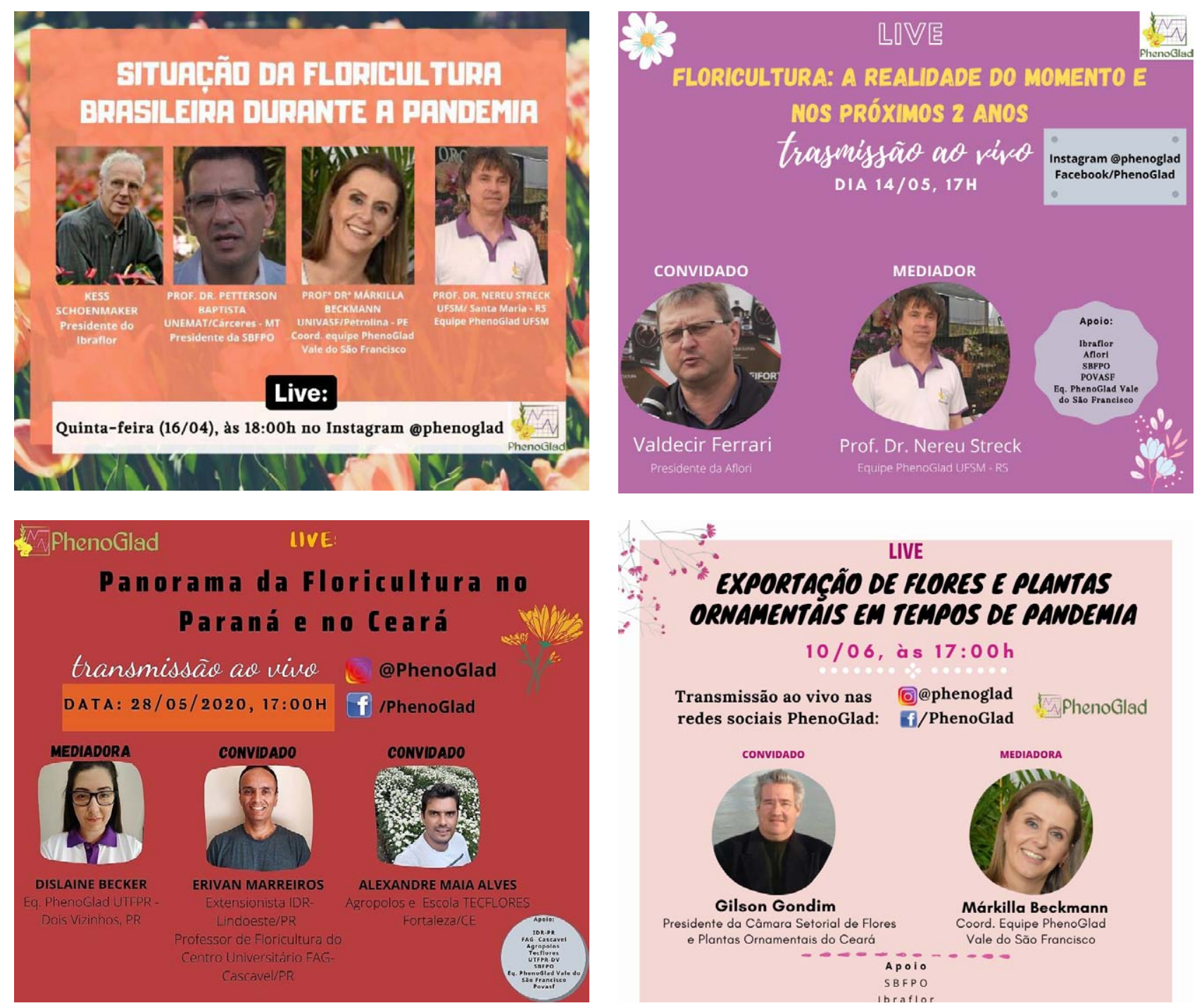

Figure 4. Photos to publicize the themes of some lives carried out by the Phenoglad team: (A) Situation of Brazilian floriculture during the pandemic; (B) Floriculture, the reality of the moment and the next 2 years; (C) Panorama of floriculture in Paraná State and Ceará State, Brazil; (D) Export of flowers and ornamental plants in times of pandemic.

In addition to lives, social networks were one of the main directions for companies to encourage the consumption of flowers and ornamental plants, especially for Mother's Day (Figure 5). The IBRAFLOR (Brazilian Institute of Floriculture), Veiling Holambra, Cooperflora, and even the State Secretariat of Agriculture, Livestock and Supply of Minas Gerais, among others, published pieces that showed the association between receiving flowers and happiness, well being, provided by a gesture of affection, even from a distance (Cooperflora, 2020; Ibraflor, 2020; Minas Gerais, 2020; Veiling Holambra, 2020a). 

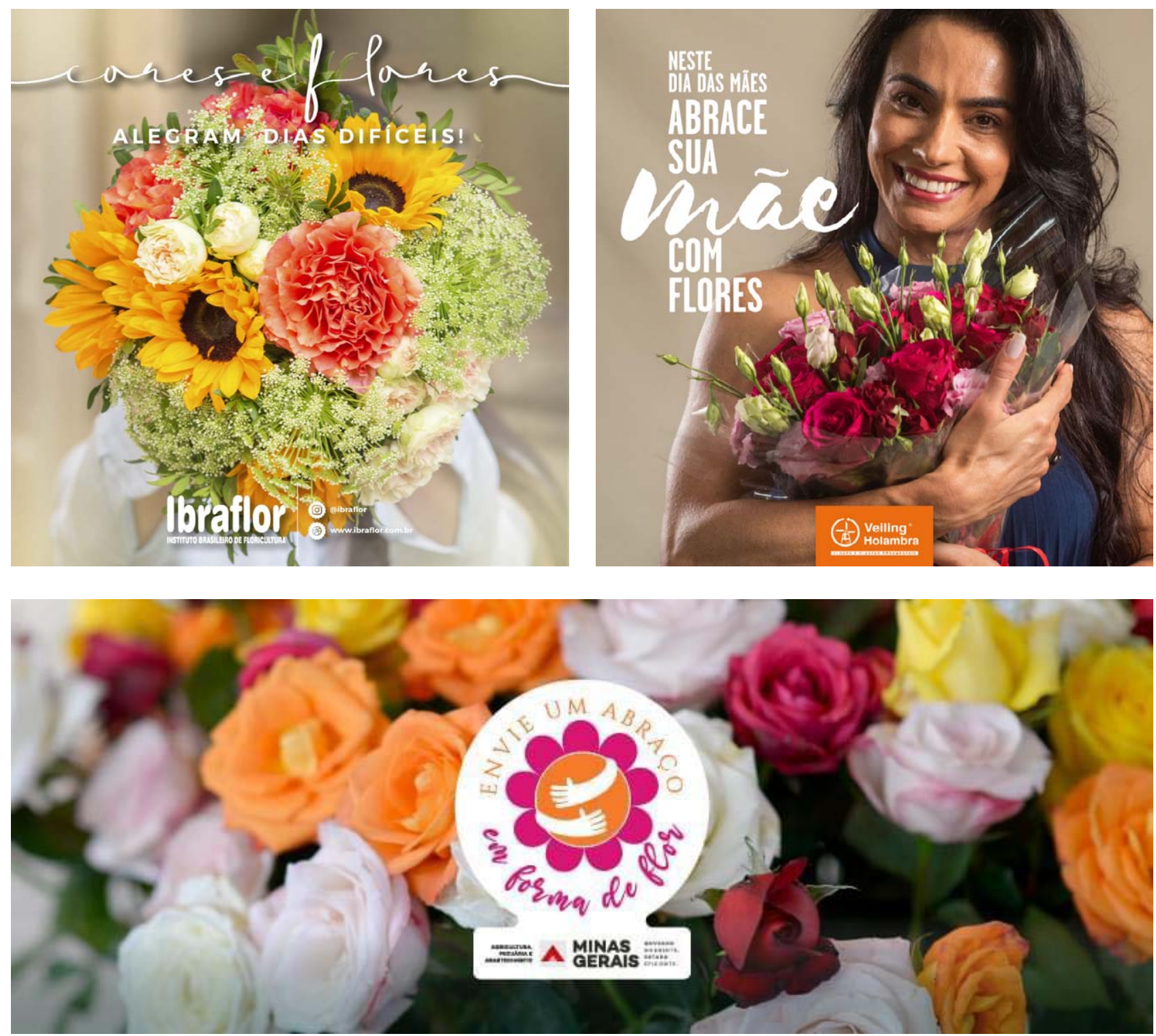

Figure 5. Campaigns to encourage the consumption of flowers. Source: IBRAFLOR, Veiling Holambra, Secretariat of Agriculture, Livestock and Supply of Minas Gerais State, Brazil.

The main hashtags used were: "Ilive on flowers", "Flower food for soul" (\#floralimentoparaalma), "Send a hug in the form of a flower" (\#envieumabraçoemformadeflor) and "Hug your mother with flowers" (\#abracesuamaecomflores). The strategy, combined with a strong campaign by representatives of the productive sector, had an effect on Mother's Day, one of the best dates for floriculture. Sales were higher than expected for this period of crisis. After the date, the campaigns continue, showing that having flowers at home is beneficial during isolation, bringing peace and harmony to the environments.

\section{Use of technology as a way to feel close to nature}

Although contact with nature in the real world is preferred and recommended, and garden tourism is a practice that has grown in recent years (Paiva et al., 2020), the use of technologies can be an alternative in cases where contact in vivo with nature is not possible or recommended for various reasons, such as the current period of social isolation. These technologies use live recordings of nature, virtual tours in parks or botanical gardens, as well as virtual reality.

Virtual reality (VR) can trigger some responses similar to the natural environment. There are many possibilities for the use of VR technology in psychiatric and medical care (White et al., 2018), as well as during the period of social isolation. VR still presents the potential for use in patients in hospitals, thus bringing nature and its therapeutic benefits to them (Yin et al., 2020).

The Explore channel has several webcams transmitting live images of beautiful landscapes and animals from different parts of the world (Explore, 2020). It is also possible to take virtual tours in some North American parks with The Hidden Worlds of the National Parks (Google Arts \& Culture, 2020).

The botanical gardens are especially interesting for the wealth of vegetation and beautiful landscapes. Kew's Garden, one of the most famous botanical gardens in the 
world, brings a message for the virtual tour, "Stroll through our gardens from the comfort of your home" (https://www. kew.org/about-us/virtual-kew-wakehurst). Other options available are virtual tours of the Hawaii Tropical Botanical Garden, where you can dive into the world of beauty and exotic tropical vegetation, Waddesdon Manor, in England, and the Chicago Botanic Garden, in the United States (Andriotis, 2018).

The Keukenhof tulip park offers a spectacle to its visitors every year: there are 32 hectares of gardens that have as their main attraction beautiful varieties of tulips. The park opens only a few months a year, from March to May and, with the pandemic, it did not receive visitors in 2020. But with the gardens ready and beautiful flowers comprising the landscape, several videos were made available to present the different areas of the park and, beyond the beautiful images, explanations about some spaces can be heard, provided by professionals who worked on their creation and implantation (Keukenhof, 2020).

The renowned French painter Claude Monet had a strong relationship with nature, where he was inspired to compose his paintings, which are admired worldwide. Monet said "My garden is my most beautiful work of art". Its garden still impresses today and it is possible to take a virtual tour to get to know it. Another tourist spot that adopted the virtual tour is the Versailles Palace: several materials were made available on the internet: readings, tests, audios, music, videos and even games for children, allowing alternative forms of interaction (Tempes Réel 78, 2020).

In Brazil, the Botanical Garden of São Paulo offers a virtual tour of its 360 thousand square meters, full of plants and flowers from Brazil and other parts of the world (Jardim Botânico de São Paulo, 2020). Through an application created by students from Universidade Federal Rural de Pernambuco (UFRPE), it is possible to visit the Botanical Garden of Recife. The application presents texts, photos, maps and audios (Pernambuco, 2020).

The Inhotim Institute, in Brumadinho, Minas Gerais, uses Google Art \& Culture to make the art and landscape collection available. The tool follows the same line as Google Street View, so it is possible to "walk" through the gardens and observe the artistic exhibitions. Parque das Mangabeiras in the state capital also offers a similar experience.

These technologies are particularly interesting since, despite their limitations, they still allow to maintain some of the benefits of having this contact with nature and, in times of isolation, it is possible to take advantage of this.

\section{Conclusions}

Flowers and ornamental plants present in the gardens or in pots inside houses, the grassy areas, besides nature virtually exposed add beauty to the environments and bring greater well-being, stimulating creativity and happiness. These characteristics are very important to assist in facing social isolation and the difficulties of the crisis experienced as a result of the Covid-19 pandemic.

\section{Author contribution}

S.N.R.: idea, bibliographic review and article writing; M.V.R.: bibliographic review and article writing; A.M.P.N.: bibliographic review and article writing.

\section{Acknowledgements}

The authors would like to thank FAPEMIG, CNPq and Capes for granting scholarships and financing projects.

\section{References}

ACTOEP-AssociaçãoCulturaldos Terapeutas Ocupacionais do Estado do Paraná. Orientações práticas para rotinas saudáveis: aprendendo a lidar com as mudanças de rotina devido ao COVID-19. 2020. Available at: https://2e50ceef-db66-47c3-9bbc-00044d447c12.filesusr. com/ugd/865ed2_ef701318dec5456b8159f07e646c59b3. pdf. Accessed on: May 14, 2020.

AGRELA, L.; CURY, M.A.; VITORIO, T. Na quarentena, o mundo virou uma live. 2020. Available at: https:// exame.abril.com.br/revista-exame/o-mundo-e-uma-live/. Accessed on: May 18, 2020.

AHTA - American Horticultural Therapy Association. History of horticultural therapy. 2020. Available at: https://www.ahta.org/history-of-horticultural-therapy. Accessed on: May 17, 2020.

AMARAL, J.L.G. COVID-19, 30 dias no Brasil. 2020. Available at: http://associacaopaulistamedicina.org.br/noticia/ covid-19-30-dias-no-brasil. Accessed on: May 11, 2020.

ANDRIOTIS, M.E. 5 gardens you can virtually tour, just in time for the first day of spring. 2018. Available at: https:/www.housebeautiful.com/lifestyle/gardening/ g31746949/gardens-you-can-virtually-tour/. Accessed on: June 15, 2020.

ARMSTRONG, D. A survey of community gardens in upstate New York implications for health promotion and community development. Health and Place, v.6, n.4, p.319-327, 2000. DOI: https://doi.org/10.1016/S1353-8292(00)00013-7.

AYDOGAN, A.; CERONE, R. Review of the effects of plants on indoor environments. Indoor and Built Environment, Online First, 2020. DOI: https://doi. org/10.1177/1420326X19900213

BEZERRA, A.; SILVA, C.E.M.; SOARES, F.R.G.; SILVA, J.A.M. Fatores associados ao comportamento da população durante o isolamento social na pandemia de COVID-19. 2020. Available at: http://www.cienciaesaudecoletiva. com.br/artigos/fatores-associados-ao-comportamento-dapopulacao-durante-o-isolamento-social-na-pandemia-decovid19/17551 Accessed on: May 9, 2020. 
BRATMAN, G.N.; HAMILTON, J.P.; DAILY, G.C. The impacts of nature experience on human cognitive function and mental health. Annals of the NewYork Academy of Science, v.1249, p.118-136, 2012. DOI: https://doi. org/10.1111/j.1749-6632.2011.06400.x

BUCKLEY, R. Nature tourism and mental health: parks, happiness, and causation. Journal of Sustainable Tourism, v.28, n.9, p.1409-1424, 2020. DOI: https://doi.or $\mathrm{g} / 10.1080 / 09669582.2020 .1742725$

CANAL TERRA VIVA. Amanhã, às 10h, no nosso Instagram@canalterraviva! Não perca! Esperamos vocês! Participem! 2020. São Paulo, 21 abril 2020. Instagram: @canalterraviva. Available at: https://www. instagram.com/p/B_QkcwqnB38/. Accessed on May 16, 2020 .

CANTOR, B.E.M.; SINGUREANU, V.; HUSTI, A.; HORT, D.; BUTA, M. Ornamental plants used for improvement of living, working and studying spaces microclimate. ProEnvironment, v.6, p.562-565, 2013.

CECCON, R.F.; SCHNEIDER, I.J.C. Light technologies in the pandemic times: Health education as a device to fight the Coronavirus. 2020. Available at: https://preprints.scielo. org/index.php/scielo/preprint/view/136/160. Acessed on: May 10, 2020.

CETINKAYA, G.; ÇIFTÇIOĞLU, G.Ç. Exploring the function of home gardens in strengthening the resilience of social-ecological landscapes through cross-scale interactions: a case study from lefke city of the Northern Cyprus. Resilience Journal, v.3, n.2, p.327-347, 2019. DOI: https://doi.org/10.32569/resilience.620885

CHANG, C.Y.;CHEN, P. K. Human response to window views and indoor plants in the workplace. HortScience, v.40,n.5,p.1354-1359,2005.DOI: https://doi.org/10.21273/ hortsci.40.5.1354

CHIMENTTI, B.; CRUZ, P.G. 2006. Um jardim deve ser possível para todos. Available at: http://www.casaecia.arq. br/jardim_sensorial.htm. Accessed on: May 17, 2020

CIFTCIOGLU, G.C.; EBEDI, S.; ABAK, K. Evaluation of the relationship between ornamental plants - based ecosystem services and human wellbeing: A case study from Lefke Region of North Cyprus. Ecological Indicators, n.102, p.278-288. 2019. DOI: https://doi.org/10.1016/j. ecolind.2019.02.048

CONSTANTINO, N.R.T. Novas funções do paisagismo: jardins terapêuticos. São Paulo: Unesp, 2004.

COOPER, M.C. Help with Healing: green place. UK: Landscape Design, 2005.
COOPERFLORA. Cuidar de quem tanto cuida. Holambra, 24 abril 2020. Instagram: @cooperflora. Available at: https://www.instagram.com/p/B_X0awlHjMC/. Accessed on: May 28, 2020.

DENG, L.; DENG, Q. The basic roles of indoor plants in human health and comfort. Environmental Science and Pollution Research, v.25, p.36087-36101, 2018. DOI: https://doi.org/10.1007/s11356-018-3554-1

PERNAMBUCO. Diário de Pernambuco. Jardim Botânico do Recife disponibiliza passeio virtual através de aplicativo. 2020. Available at: https://www.diariodepernambuco.com. br/noticia/vidaurbana/2020/04/jardim-botanico-do-recifedisponibiliza-passeio-virtual-atraves-de-apl.html Accessed May 26, 2020.

DYG, P. M.; WISTOFT, K. Wellbeing in school gardens the case of the Gardens for Bellies food and environmental education program. Environmental Education Research, v.24, n.1-15, 2018.

ELSADEK, M.; LIU, B.; LIAN, Z. Green façades: their contribution to stress recovery and well-being in highdensity cities. Urban Forestry and Urban Greening, Article 126446, v.46, 2019. DOI: https://doi.org/10.1016/j. ufug.2019.126446

EMATER MINAS. O "Emater Ao Vivo" desta semana é delas, as profissionais da Extensão Rural! Belo Horizonte, 04 maio 2020. Instagram: @ematerminas. Avaiable at: https://www.instagram.com/p/B_xoYi_HOJA/. Acessed on: June 15, 2020.

EXPLORE. Livecams / currently live. 2020. Available at: https:/explore.org/livecams/currently-live. Acessed on: May 18, 2020.

FAGERHOLM, N.; MARTÍN LÓPEZ, B.; TORRALBA, M.; OTEROS ROZAS, E.; LECHNER,A.M.; BIELING, C.; STAHL OLAFSSON, A.; ALBERT, C.; RAYMOND, C.M.; GARCIA MARTIN, M.; GULSRUD, N.; PLIENINGER, T. Perceived contributions of multifunctional landscapes to human well being: Evidence from 13 European sites. People and Nature, v.2, n,1, p. 217-234, 2020. DOI: https://doi.org/10.1002/pan3.10067

FENG, H.; HEWAGE, K. Lifecycle assessment of living walls: air purification and energy performance. Journal of Cleaner Production, v.69, p.91-99, 2014. DOI: https://doi. org/10.1016/j.jclepro.2014.01.041

FERREIRA JR., J.B.; FREITAS, E.D.S.; CHAVES, S.F.N. Exercise: a protective measure or an "open window" for COVID-19? A Mini Review. Frontiers in Sports and Active Living, v.2, 2020. DOI: https://doi.org/10.3389/ fspor.2020.00061 
FJELD, T.; VEIERSTED, B.; SANDVIK, L.; RIISE, G.; LEVY, F. The effect of indoor foliage plants on health and discomfort symptoms among office workers. Indoor and Built Environment, v.7, n.4, p.204-209, 1998. DOI: https://doi.org/10.1159/000024583

FLORAL ATLANTA. Vem aí! \#floresemcasa. Diadema, March 31 2020. Instagram:@floralatlanta. Available at: https://www.instagram.com/p/B-aAyC3nSj-/. Acessed on: May 15, 2020.

FONSECA, I.; PORTO, M.M. Cor e luz na arquitetura: e suas possíveis influências sobre os usuários. Lume Arquitetura, n.14, p.24-29, 2005

GAPPELL, M. Psychoneuroimmunology. In: MARBERRY, S.O. (org.) Innovations in Healthcare Design: selected presentations from the first five Symposia on Healthcare Design. New York: John Wiley \& Sons, 1995. p.115-120.

GARBUZOV, M.; FENSOME, K.A.; RATNIEKS, F.L.W. Public approval plus more wildlife: Twin benefits of reduced mowing of amenity grass in a suburban public park in Saltdean, UK. Insect Conservation and Diversity, v.8, n.2, p.107-119, 2015. DOI: https://doi.org/10.1111/icad.12085

GHIMIRE, M.; BOYER, T.A.; CHUNG, C.; MOSS, J.Q. Consumers' shares of preferences for turfgrass attributes using a discrete choice experiment and the best-worst method. HortScience, v.51, n.7, p.892-898, 2016. DOI: https://doi.org/10.21273/HORTSCI.51.7.892

GOOGLE ARTS \& CULTURE. The hidden worlds of the national parks. 2020. Available at: https://artsandculture. withgoogle.com/en-us/national-parks-service/parks Accessed on: May 18, 2020.

IBRAFLOR. Instituto Brasileiro de Floricultura. Dia das mães. Holambra, 03 maio 2020. Instagram: @ ibraflor. Available at: https://www.instagram.com/p/B vCUn1HE7_. Accessed on: June 15, 2020.

IRGA, P.J.; PETTIT, T.J.; TORPY, F.R. The phytoremediation of indoor air pollution: a review on the technology development from the potted plant through to functional green wall biofilters. Reviews in Environmental Science and Biotechnology, v.17, n.2, p.395-415, 2018. DOI: https://doi.org/10.1007/s11157-018-9465-2

JARDIM BOTÂNICO DE SÃO PAULO. 2020. Tour Virtual 360 ${ }^{\circ}$. Available at: http://www.ibot.sp.gov.br/jardim/ tour\%20virtual/index.html Accessed on: June 21, 2020.

KENIGER, L.; GASTON, K.;IRVINE, K.; FULLER, R. What are the Benefits of Interacting with Nature? International Journal of Environmental Research and Public Health, v.10, n.3, p.913-935, 2013. DOI: https:// doi.org/10.3390/ijerph10030913
KEUKENHOF. Keukenhof virtually open. 2020. Available at: https://keukenhof.nl/en/keukenhof-virtuallyopen-2/ Accessed on: May 22, 2020.

LOUV, R. A última criança na natureza. São Paulo: Aquariana, 2016.

MINAS GERAIS. Secretaria de Agricultura de Minas Gerais. Envie um abraço em forma de flor. Belo Horizonte, 05 maio 2020. Instagram: @secretariadeagricultuamg. Available at: https://www.instagram.com/p/B_0fBEZFJa8/. Accessed on: May 5, 2020.

NASA. (n.d.). Plants clean air and water for indoor environments. Available at: https://spinoff.nasa.gov/ Spinoff2007/ps_3.html Accessed on: May 14, 2020.

NORWOOD, M.F.; LAKHANI, A.; MAUJEAN, A.; ZEEMAN, H., CREUX, O.; KENDALL, E. Brain activity, underlying mood and the environment: a systematic review. Journal of Environmental Psychology, Article 101321, v.65, 2019. DOI: https://doi.org/10.1016/j. jenvp.2019.101321

ODEH, R.; GUY, C.L. Gardening for therapeutic peopleplant interactions during long-duration space missions. Open Agriculture, v.2, n.1, p.1-13.2017. DOI: https://doi. org/10.1515/opag-2017-0001

ORWELL, R.L.; WOOD, R.L.; TARRAN, J.; TORPY, F.; BURCHETT, M.D. Removal of benzene by the indoor plant/ substrate microcosm and implications for air quality. Water, Air, and Soil Pollution, v.157, p.193-207, 2004. DOI: https:/doi.org/10.1023/B:WATE.0000038896.55713.5b

OYABU, T.; SAWADA, A.; ONODERA, T.; TAKENAKA, B.; WOLVERTON, B. Characteristics of potted plants for removing offensive odors. Sensors and Actuators B: Chemical, v.89, n.3, p.131-136, 2003. DOI: https://doi. org/10.1016/S0925-4005(02)00454-9

PAHO. Pan American Health Organization. Folha informativa - COVID-19 (doença causada pelo novo coronavirus). 2020a. Available at: https://www.paho.org/ bra/index.php?option $=$ com_content $\&$ view $=$ article \&id $=61$ 01:covid19\&Itemid=875. Accessed on: May 11, 2020.

PAHO. Pan American Health Organization. Medidas não farmacológicas de saúde pública para mitigação de risco e impacto de epidemias e pandemias de influenza. 2020b. 86p. Available at: https://iris.paho.org/ bitstream/handle/10665.2/52044/9789275722220_por. pdf? sequence $=1 \&$ isAllowed $=y$. Accessed on: May 11, 2020 .

PAIVA, P.D.O. Paisagismo: conceitos e aplicações. Lavras: Editora UFLA, 2008, 608p. 
PAIVA, P.D.O.; SOUSA, R.B. CARCAUD, N. Flowers and gardens on the context and tourism potential. Ornamental Horticulture, v.26, n.1, p.121-133, 2020. DOI: https://doi. org/10.1590/2447-536x.v26i1.2144.

PETTIT, T.; IRGA, P. J.; TORPY, F.R. Towards practical indoor air phytoremediation: a review. Chemosphere, v.208, p.960-974, 2018. DOI: https://doi.org/10.1016/j. chemosphere.2018.06.048

PHENOGLAD. 2020. Como está a situação da cadeia da Floricultura e Plantas Ornamentais neste momento da pandemia? Santa Maria, 15 abril 2020. Instagram: @ phenoglad. Available at: https://www.instagram.com/p/B A1HFyB6i7/. Accessed on: May 25, 2020.

PRETTY, J.; PEACOCK, J.; HINE, R.; SELLENS, M.; SOUTH, N.; GRIFFIN, M. Green Exercise in the uk countryside: effects on health and psychological well-being, and implications for policy and planning. Journal of Environmental Planning and Management, v.50, n.2, p.211-231, 2007. DOI: https://doi. org/10.1080/09640560601156466

RELF, D. Human issues in horticulture. HortTechnology, v.2, p.159-287, 1992.

SANTOS, L.P.S.; CUBA, R.M.F.; LEITÃO, V.S.; SANTOS NETO, A.S.S. Análise da eficiência de calçadas ecológicas como sistema de drenagem sustentável nos centros urbanos: estudo de caso no Parque Flamboyant, Goiânia-Goiás. Electronic Journal of Management, Education and Environmental Technology, v.19, n.3, p.837-849, 2015. DOI: https://doi.org/10.5902/22361170

SANTOS, P.L.F.; BARCELOS, J.P.Q.; CASTILHO, R.M.M. Diferentes substratos no desenvolvimento de um gramado ornamental para uso em telhados verdes. Periódico Técnico e Científico Cidades Verdes, v.4, n.10, p.81-94, 2016. DOI: http://dx.doi.org/10.17271/23178604 41020161393

SHAO, Y., ELSADEK, M.; LIU, B. Horticultural activity: its contribution to stress recovery and wellbeing for children. International journal of environmental research and public health, v.1, n.4, 1229, 2020. DOI: https://doi.org/10.3390/ijerph17041229

SISWANTO, D; PERMANA, B.H; TREESUBSUNTORN, C; THIRAVETYAN, P. Sansevieria trifasciata and Chlorophytum comosum botanical biofilter for cigarette smoke phytoremediation in a pilot-scale experiment -evaluation of multi-pollutant removal efficiency and $\mathrm{CO} 2$ emission. Air Quality, Atmosphere and Health, v.13, n.1, p.109-117, 2020. DOI: https://doi.org/10.1007/s11869019-00775-9
SOGA, M.; GASTON, K.J.; YAMAURA, Y. Gardening is beneficial for health: a meta-analysis. Preventive Medicine Reports, v.5, p.92-99, 2017. DOI: https://doi. org/10.1016/j.pmedr.2016.11.007

SOUZA, F.H.D.; GUSMÃO, M.R.; MATTA, F.P.; CASTRO, A.C.R.; MITTELMANN, A.; FÁVERO, A.P.; JANK, L. Atributos desejáveis para gramados a serem cultivados sob condições brasileiras: uma proposta. Ornamental Horticulture, v.22, n.2, p.154-165, 2016.

SOUZA, T.S.; $\quad$ MIRANDA, M.B.S. Horticultura como tecnologia de saúde mental. Revista Psicologia, Diversidade e Saúde, v.6, n.4, p.310323, 2017. DOI: DOI: http://dx.doi.org/10.17267/23173394rpds.v6i4.1662

STIER, J.C.; STEINKE, K.; ERVIN, E.H.; HIGGINSON, F.R.; McMAUGH, P.E. Turfgrass benefits and issues. In: STIER, J.C.; HORGAN, B.P.; BONOS, S.A. (eds.). Turfgrass: biology, use, and management. Madison: ASA, CSSA, SSSA, 2013. p.105-145.

TEMPES RÉEL 78. Coronavirus: découvrez le château de Versailles depuis chez vous pendant le confinement. 2020. Available at: https://tr78.fr/coronavirus-decouvrezle-chateau-de-versailles-depuis-chez-vous-pendant-leconfinement Accessed on: May 26, 2020.

ULLAH, H.; TREESUBSUNTORN, C.; THIRAVETYAN, P. Application of exogenous indole-3-acetic acid on shoots of Zamioculcas zamiifolia for enhancing toluene and formaldehyde removal. Air Quality, Atmosphere \& Health, v.13, p.575-583, 2020. DOI: https://doi. org/10.1007/s11869-020-00820-y

ULRICH, R.S. Visual landscapes and psychological wellbeing, Landscape Research, v.4, n.1, p.17-23, 1979. DOI: https://doi.org/10.1080/01426397908705892

ULRICH, R.S.; SIMONS R.F.; LOSITO B.D.; FIORITO E.; MILES M.A.; ZELSON, M.; Stress recovery during exposure to natural and urban environments, Journal of Environmental Psychology, v.11, n.3, p.201-230, 1991. DOI: https://doi.org/10.1016/S0272-4944(05)80184-7

UN. United Nations. 2020 Policy Brief: COVID-19 and the Need for Action on Mental Health. Available at: https://www.un.org/sites/un2.un.org/files/un_policy_briefcovid_and_mental_health_final.pdf. Accessed on: May 14, 2020 .

VAN DEN BERG, A.E.; MAAS, J.; VERHEIJ, R.A.; GROENEWEGEN, P.P. Green space as a buffer between stressful life events and health. Social Science and Medicine, v.70, n.8, p.1203-1210, 2010. DOI: https://doi. org/10.1016/j.socscimed.2010.01.002 
VEILING HOLAMBRA. Buquês criativos. Holambra, 27 maio 2020a Instagram: @veilingholambra. Available at: https://www.instagram.com/p/CAtHShDp2 O/. Accessed May 29, 2020.

VEILING HOLAMBRA. Elas merecem esse abraço. Holambra, 23 abril 2020b. Instagram: @veilingholambra. Available at: https://www.instagram.com/p/B VX0HJp2br/. Accessed on: May 29, 2020.

WANG, C.; HORBY, P.W.; HAYDEN, F.G.; GAO, G.F. A novel coronavirus outbreak of global health concern. Lancet, v.395, p.470-473, 2020. DOI: https://doi. org/10.1016/S0140-6736(20)30185-9

WHITE, M.P.; YEO, N.L.; VASSILJEV, P.; LUNDSTEDT, R.; WALLERGÅRD, M.; ALBIN, M.; LÕHMUS, M. A prescription for "nature" - the potential of using virtual nature in therapeutics. Neuropsychiatric disease and treatment. v.14, p.3001-3013, 2018, DOI:10.2147/NDT. S179038

WHO. World Health Organization. Advice on the use of masks in the context of COVID-19: interim guidance. 2020a. Available at: https://apps.who.int/iris/ handle/10665/332293. Accessed on: June 15, 2020.

WHO. World Health Organization. Q\&A: Violence against womenduringCOVID-19.2020b.Availableat:https://www. who.int/emergencies/diseases/novel-coronavirus-2019/ question-and-answers-hub/q-a-detail/violence-againstwomen-during-covid-19?gclid=CjwKCAjw5vz2BRAtEi wAbcVILz8qCw9iTKLTATXU-4V5eSueCJFczQ-lqVQJ z1I_MVSp6ByZyqAWBoCkWsQAvD_BwE. Accessed on: June 15, 2020.
WOLVERTON, B.C.; JOHNSON, A.; BOUNDS, K. Interior landscape plants for indoor air pollution abatement. 1989. Avaliable at: https://ntrs.nasa.gov/ search.jsp?R=19930073077 Accessed on: June 17, 2020.

YIN, J.; YUAN, J.; ARFAEI, N.; CATALANO, P. J.; ALLEN, J. G.; SPENGLER, J. D.. Effects of biophilic indoor environment on stress and anxiety recovery: a between-subjects experiment in virtual reality. Environment International, v.136, n.3, 105427, 2020. DOI: https://doi.org/10.1016/j.envint.2019.105427

YIN, J.; ZHU, S.; MACNAUGHTON, P.; ALLEN, J.G.; SPENGLER, J.D. Physiological and cognitive performance of exposure to biophilic indoor environment. Building and Environment, v.132, n.3, p.255-262, 2018. DOI: https:// doi.org/10.1016/j.buildenv.2018.01.006

YU, J.; CHAI, P.; GE, S.; FAN, X. Recent understandings toward Coronavirus disease 2019 (COVID-19): from bench to bedside. Frontiers in Cell Development Biology, v.8, n.476, 2020. DOI: https://doi.org/10.3389/fcell.2020.00476 